\title{
Heart pathomorphological changes in the long-term alcohol consumption
}

\author{
S. I. Tertyshnyi ${ }^{\star A, B, D, E, F}$, T. V. Shuliatnikova ${ }^{A, D, E}$, M. D. Zubko ${ }^{B} B, C$ \\ Zaporizhzhia State Medical University, Ukraine
}

A - research concept and design; B - collection and/or assembly of data; C - data analysis and interpretation; D - writing the article; $\mathrm{E}$ - critical revision of the article; $\mathrm{F}$ - final approval of the article

Alcohol is one of the leading causes of death worldwide, annually taking 3 million lives. Alcohol abuse to a greater degree negatively affects the functioning of the cardiovascular system.

Aim. Studying the severity of pathomorphological changes in the heart of deceased patients with alcoholism.

Materials and methods. The heart sections of 35 deceased alcoholic patients (38-60 years old) were taken for histo-morphometric analysis. As a comparison group, the material of deceased patients $(n=15)$, suffering from ischemic heart disease (IHD) and hypertension disease (HD) was studied.

Results. In conditions of alcoholism in $100 \%$ of cases myocardium showed marked microcirculatory disorders, increased vascular permeability. In all cases sclerotic changes similar in topography to the comparison group were noted, however, sclerosis of large arterioles was 1.9 times less pronounced than in IHD group. In the myocardium of alcoholics, edema, atrophy of cardiomyocytes bundles and areas of fatty stroma are common. In $20 \%$ of cases, there were mosaic necrosis of individual cardiomyocytes and small focal necrosis of small groups of cells, fibrinoid necrosis of small branches of coronary arteries. Compared with IHD group the number of fatty degenerated cardiomyocytes increased by 1.23 times, fuchsinophilic cardiomyocytes - by 1.38 times with simultaneous reducing severity of sclerotic changes in vessels by 1.9 times. Sclerotic changes in stroma are significantly higher in relation to IHD and HD groups (by 1.88 and 6.94 times, respectively).

Conclusions. The morphogenesis of heart damage during alcoholism consists of combination of dystrophic, necrotic, atrophic and sclerotic changes - morphological substrate of alcoholic cardiomyopathy. These signs, based on quantitative analysis, are important criteria necessary for the thanatogenetic analysis in cases of death on the background of alcoholism.

\section{Патоморфологічні зміни в серці в умовах тривалого вживання алкоголю}

\section{С. І. Тертишний, Т. В. Шулятнікова, М. А. Зубко}

Алкоголь - одна з основних причин смертності в усьому світі, яка щорічно забирає 3 мільйони життів. Тривалий вплив алкоголю призводить до ураження серцево-судинної системи, зумовлюючи її недостатність.

Мета роботи - вивчити вираженість патоморфологічних змін в серці хворих з алкоголізмом, які померли.

Матеріали та методи. Здійснили гістоморфологічний аналіз препаратів серця 35 померлих віком від 38 до 60 років, які тривало зловживали алкоголем. Як групу порівняння вивчили зміни в серці померлих $(n=15)$, які страждали на ішемічну хворобу серця (IXC) і гіпертонічну хворобу (ГX).

Результати. В умовах тривалого зловживання алкоголем в міокарді в 100 \% спостережень виявили виражені мікроциркуляторні розлади. В усіх спостереженнях наявні склеротичні зміни, аналогічні за топографрією до тих, що визначені в групі порівняння; однак склеротичні зміни в великих артеріолах були в 1,9 раза менше виражені, ніж у хворих на IXC. У стромі виявили ділянки жирової дистрофрії. У 20 \% спостережень в міокарді визначали мозаїчні некрози окремих кардіоміоцитів і дрібні ділянки некрозу незначних груп кардіоміоцитів, фібриноїдний некроз стінок дрібних гілок коронарних артерій. У міокарді померлих з алкоголізмом в 1,23 раза збільшується кількість кардіоміоцитів у стані жирової дистрофії, в 1,38 раза - кількість фуксинофільних кардіоміоцитів. У судинах в 1,9 раза менше виражені склеротичні зміни порівняно з групою IXC. Склеротичні зміни в стромі вірогідно вираженіші в групі з алкоголізмом, порівнюючи 3 померлими з ІХС і ГБ (в 1,88 і 6,94 раза відповідно).

Висновки. Морфогенез ураження серця в умовах тривалого зловживання алкоголем складається з дистрофічних, некротичних, атрофічних і склеротичних змін, що є морфологічним субстратом алкогольної кардіоміопатії. Встановлені із застосуванням якісного та кількісного методів порівняльного аналізу патоморфологічні зміни в міокарді, що виникають при алкоголізмі, - важливі морфологічні критерії, необхідні для аналізу танатогенезу і встановлення безпосередньої причини смерті.
Key words: alcoholism, heart, pathology.

Pathologia 2020; 17 (2), 149-155

*E-mail: tertishniy@i.ua

Киючові слова: алкоголізм, серце, патогістологічні зміни.

Патологія. 2020.

T. 17, № 2(49)

C. $149-155$

\section{Патоморфологические изменения в сердце в условиях Алительного употребления алкоголя}

Ключевые слова: алкоголизм, серАце, патогистологические изменения.

Патология. 2020

T. 17, № 2(49),

C. $149-155$

Алкоголь - одна из основных причин смертности во всем мире, ежегодно забирающая 3 миллиона жизней. Длительное воздействие алкоголя приводит к значительному повреждению сердечно-сосудистой системы, вызывая ее недостаточность. 
Цель работы - изучить выраженность патоморфологических изменений в сердце умерших больных с алкоголизмом.

Материалы и методы. Проведен гистоморфометрический анализ препаратов сердца 35 умерших больных алкоголизмом в возрасте от 38 до 60 лет. Как группа сравнения изучены изменения в сердце умерших больных $(\mathrm{n}=15)$, страдавших ишемической болезнью сердца (ИБС) и гипертонической болезнью (ГБ).

Результаты. При алкоголизме в миокарде умерших в 100 \% наблюдений отмечены выраженные микроциркуляторные расстройства, признаки повышенной сосудистой проницаемости. Во всех наблюдениях отмечены склеротические изменения, аналогичные по топографии группе сравнения, однако склероз крупных артериол в 1,9 раза менее выражен, чем у больных с ИБС. В миокарде умерших с алкоголизмом распространены отек, атрофия пучков кардиомиоцитов, жировая дистрофия стромы. В 20 \% наблюдений в миокарде отмечены мозаичные некрозы отдельных кардиомиоцитов, участки некроза групп кардиомиоцитов, фибриноидный некроз стенок мелких ветвей коронарных артерий. В миокарде умерших с алкоголизмом в 1,23 раза увеличивается количество кардиомиоцитов в состоянии жировой дистрофии, в 1,38 раза увеличивается количество фуксинофильных кардиомиоцитов. В сосудах в 1,9 раза менее выражены склеротические изменения при сравнении с группой ИБС. Склеротические изменения в строме достоверно более выражены в группе с алкоголизмом в сравнении с умершими с ИБС и ГБ (в 1,88 и 6,94 раза соответственно).

Выводы. Морфогенез поражения сердца при алкоголизме складывается из дистрофических, некротических, атрофических и склеротических изменений, образующих морфологический субстрат алкогольной кардиомиопатии. Установленные с использованием качественных и количественных методов сравнительного анализа патоморфологические изменения в миокарде, возникающие при алкоголизме, - важные морфологические критерии, необходимые для анализа танатогенеза и установления непосредственной причины смерти.

Alcoholism continues to be one of the main causes of preventable mortality worldwide, causing 3 million deaths annually [1]. In terms of mortality, alcoholism currently ranks third place in world statistics, yielding to ischemic heart disease (IHD) and neoplasms. According to WHO statistics for 2012, Ukraine ranked fifth in the world in terms of alcohol consumption and second in terms of mortality from alcoholism. Also, according to WHO, Ukraine ranks first in the world in terms of child alcoholism. In Ukraine, about 40 thousand people die from alcoholism every year.

The damaging effect of long-maintained high doses of alcohol is most directed to the cardiovascular system $[8,9]$. Alcoholism is often a direct cause of hypertension [2,3], non-ischemic dilated cardiomyopathy [4], atrial fibrillation [5,6], and stroke [7]. The effect of ethanol and its metabolites on the myocardium leads to the formation of alcoholic cardiomyopathy, which is detected, as a rule, at the late stages of alcoholism [10]. It is known that in sudden death on the background of alcohol intoxication, morphological signs of myocardial dystrophy were detected in $35-50 \%$ of cases [10].

At present, the pathogenetic mechanisms of myocardial damage in chronic alcohol intoxication have been studied quite well $[11,12]$, however, the description of pathomorphological changes in the heart of those who died in alcoholism is limited - in a few works of recent years [13].

\section{Aim}

To determine the severity of pathomorphological changes in the heart of deceased patients with alcoholism.

\section{Material and methods}

The pathomorphological study based on the results of 35 autopsies of deceased patients with alcoholism (30 men and 5 women) aged 38 to 60 years who were treated in Zaporizhzhia Regional Neuropsychiatric Dispensary. The inclusion criterion was addiction syndrome, established in accordance with ICD-10 diagnostic guidance and recorded in the medical histories of patients. As a comparison group, pathomorphological study of heart of deceased patients ( $n=15)$, suffering from IHD $(n=8)$ and hypertension disease $(H D)(n=7)$ was carried out. In the group of alcoholism, 31 observations presented by cases of chronic course of the disease, and 4 cases - by death of alcoholic patients on the background of acute alcohol excess. Cardiopulmonary insufficiency was the cause of death in $74.28 \%$ of patients ( 26 cases). In $22.85 \%$ of patients ( 8 cases) death occurred suddenly, as the result of acute left ventricular failure on the background of alcoholic cardiomyopathy. In 5 cases death occurred as the result of complications of liver cirrhosis against the background of acute hepatorenal insufficiency.

An autopsy was performed within 12-24 hours after death according to standard technique. Myocardial parts for histological examination were taken from the region of the apex, the wall of left ventricle with papillary muscles, and the interventricular septum. Fragments of coronary artery branches were also dissected. The sampling was carried out in the amount necessary for standard histological examination. Material was fixed in $10 \%$ formalin solution on $0.1 \mathrm{pH} 7.4-7.6$ phosphate buffer, embedded in paraffin; sections were prepared with a thickness of $5 \mu \mathrm{m}$. Preparations were stained with hematoxylin and eosin, picrofuchsin according to van Gieson, according to Masson. In addition, PAS reaction was used, which allows detecting weak fuchsinophilia of the damaged myocardium. To detect the loss of transverse striation in cardiomyocytes, polarization microscopy was used.

The calculation of the relative area occupied by the studied structural objects was carried out in each case in 5 standard fields of view of the Scope.A1 Carl Zeiss microscope (Germany) using Progres Gryphax Jenoptik 60N-C1"1.0 × 426114 camera (Germany) with magnification $\times 200$ and the morphometric program Videotest-Morphology 5.2.0.158 (VideoTest LLC, Russia). Statistical processing of the data was carried out using the Statistica ${ }^{\circledR}$ for Windows 13.0 package (StatSoft Inc., license No. JPZ804I382130ARCN10-J). The median (Me) and the lower and upper quartiles $(\mathrm{Q} 1 ; \mathrm{Q} 3)$ were calculated; the comparison between the two groups of observations was carried out using the Mann-Whitney U-test. Results were considered statistically significant at $95 \%(P<0.05)$. 


\section{Results}

Analyzing macroscopic changes of the comparison group where deceased suffered from IHD and HD, the heart had a characteristic macro- and microscopic picture. The myocardial consistency was tightly elastic, epicardium contained a small amount of fatty tissue; the heart cavities were often dilated, changes in the valve apparatus corresponded to the duration of the disease and the nature of the lesion. In hypertension, the valves were most often without change. With concomitant atherosclerosis, the valve cusps, especially along the trailing edge, were thickened, the chordal filaments were thickened and shortened, but there was no significant deformation of the valve cusps.

In IHD, the heart mass averaged $450.0 \pm 20.0 \mathrm{~g}$. The coronary arteries were characterized by narrowed lumens due to roundish whitish-yellow fibrous plaques, located more often segmentally, less often - in a circular character. The degree of stenosis ranged from $50 \%$ to $90 \%$. Microscopic examination revealed small focal diffuse or large focal postinfarction cardiosclerosis. At the periphery of the sclerosis sites, myocardial muscle fibers were in a state of hypertrophy. Individual cardiomyocytes and their small bundles often walled up into massive connective cords (Fig. 1). There were cardiomyocytes containing lipid inclusions, contractionally altered cardiomyocytes, partial fragmentation of muscle fibers. According to morphometry, the total area of cardiomyocytes with fatty degeneration was from $4.37(3.86 ; 5.35) \%$; foci of fuchsinophilic degeneration of cardiomyocytes -5.1 $(3.56 ; 6.56) \%$; foci of sclerosis $-8.53(7.0 ; 11.1) \%$ in a standardized field of view.

In $\mathrm{HD}$, the heart weight was in the range of $370-700 \mathrm{~g}$, an average of $505.0 \pm 20.5 \mathrm{~g}$. The wall thickness of the left ventricle was $1.8-2.5 \mathrm{~cm}$. The papillary and trabecular muscles of the left ventricle were significantly thickened. During histological examination of coronary arteries and their branches, thickening and splitting of the inner elastic membrane with growth between the membranes of the connective tissue were noted. Severe arteriolosclerosis led to a significant decrease in the cross-sectional area of the lumen of arterioles. In the circumference of sclerotized arterioles, marked hypertrophy of muscle fibers was observed, between which small foci of proliferation of fibrous tissue were determined. The cut area occupied by foci of sclerosis was $2.31(1.72 ; 2.79) \%$. Inadequate blood supply to the hypertrophic myocardium through sclerotic vessels led to the development of dystrophic changes in cardiomyocytes. Identified single cardiomyocytes in a state of fatty degeneration and contractionally altered (fuchsinophilic) cardiomyocytes. The cut area occupied by muscle fibers with fatty degeneration averaged 2.14 $(2.05 ; 2.21) \%$, fuchsinophilic myocyte degeneration occupied $1.34(1.11 ; 1.52) \%$ in a conventionally standardized field of view.

In the group of deceased patients with alcoholism, in all cases moderate or severe alcoholic cardiomyopathy detected. The heart was enlarged, its mass was $370-500 \mathrm{~g}$, on average $435.5 \pm 15.5 \mathrm{~g}$. Under the epicardium, increased accumulation of fatty tissue was detected, the apex of the heart was often rounded. The myocardium was flabby, light red, sometimes clay in ap- pearance, with a few whitish streaks. The wall thickness of the right ventricle was $0.3-0.5 \mathrm{~cm}$, the left $-1.4-1.7$ $\mathrm{cm}$. The heart cavities were dilated. The endocardium, especially of the left ventricle moderately thickened, with patches of whitish color. The walls of the coronary arteries, in those who died over the age of 50 years, in most cases were thin, elastic; flat fibrous plaques, revealed in vessels, stenosed the lumen up to $20-30 \%$.

Microscopic examination of the myocardium in $100 \%$ of cases showed pronounced microcirculatory disorders. Circulatory disorders affected both the arterial and venous circulatory system. Marked dyscirculatory disorders were noted: a complete decline of the lumens in some vessels and overfilling by blood the others. Part of the microvessels was filled with plasma, erythrocyte or leukocyte aggregates, hemolized erythrocytes. Meanwhile, severe circulatory disorders, their combination with pronounced changes in the perivascular space in the form of small-droplet fatty degeneration of cardiomyocytes, sclerotic changes, not accompanied by atherosclerotic changes in arteries, which was typical for IHD/HD group. In the arteries, the inner elastic membrane was clearly traced, the thickness of the muscle layer was slightly thinned, and the adventitia membrane was with areas of excision.

There were signs of increased vascular permeability: perivascular edema of varying severity, minor perivascular hemorrhages, plasmorrhagia with the accumulation of PAS-positive substances in the perivascular space. In 5 cases $(14.28 \%)$, perivascular and intramural hemorrhages, contracture lesions of varying severity and multiple foci of myocytolysis were noted (Fig. 2A). In single microvessels fibrin thrombi were found. In the history of the disease in such patients, more pronounced manifestations of heart failure were observed in vivo. In cases of death from acute coronary insufficiency, acute microcirculatory disorders were pronounced.

The presence of interstitial edema in the myocardium and atrophy of the bundles of cardiomyocytes often led to exposure of the vascular bundles, which often could be found in the loose stroma (Fig. $2 B$ ). Such microvessels had a sinuous course, often with multiple kinks. The density of adventitious cells on the surface of such vessels was uneven.

Disorders in the microvasculature were often accompanied by flattening in microvessels. A large number of fibroblasts and histiocytes appeared in such areas. Over time, obliteration of the microvessels took place, in the circumference of which the number of collagen fibers increased, spreading between myocytes over considerable distances. Dystrophic changes were observed in myocytes, which were accompanied by the loss of transverse striation, uneven staining of the cytoplasm, and fuzzy borders of individual cells, which was well detected by polarization microscopy (Fig. 3).

In the walls of the coronary arteries and their branches, one could find foci of fibrinoid necrosis, desquamation of the endothelium, plasmorrhagia, perivascular edema.

Along with microcirculatory disorders, sclerotic changes similar in topography as in the comparison group were observed in all cases. However, in the group of IHD foci of atheromatosis were detected in vessels often with 

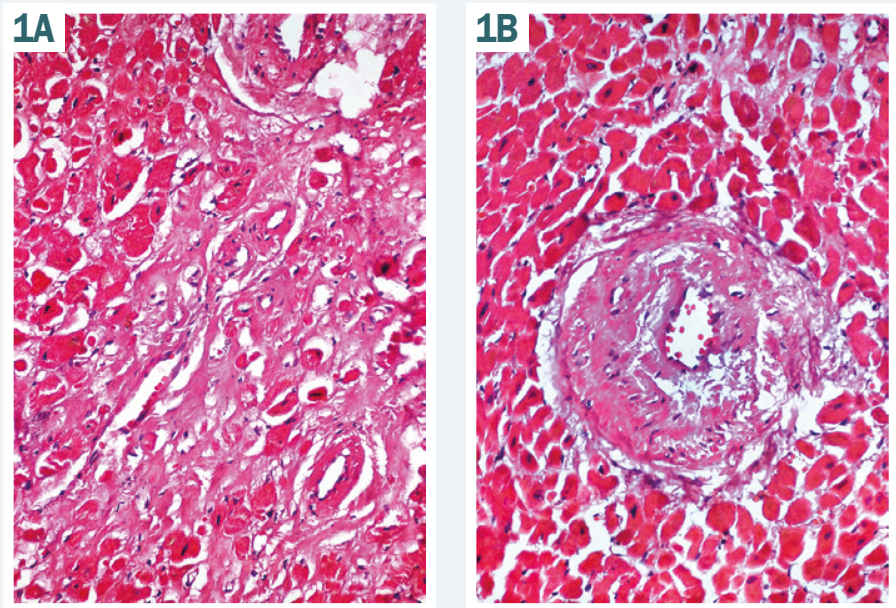

Fig. 1. A: Diffuse sclerosis and peripheral cardiomyocyte hypertrophy. IHD. B: Severe arteriolosclerosis and hypertrophy of cardiomyocytes. HD. H-E, Mag. $\times 200$.
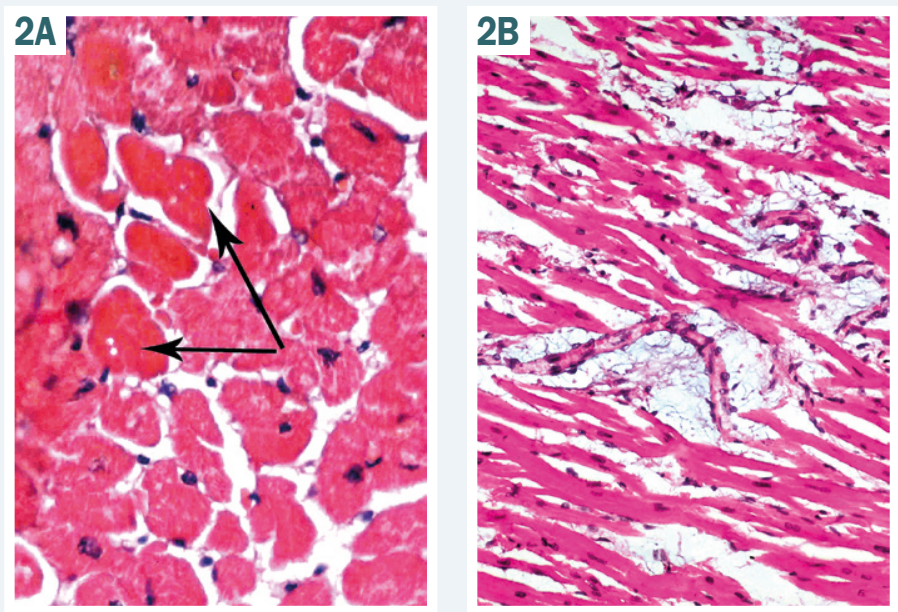

Fig. 2. A: The group of cardiomyocytes with myocytolysis (shown by arrow). H-E, Mag. $\times 400$. B: Exposure of vascular bundles in the area of atrophied myocardium. Alcoholism. H-E, Mag. $\times 200$.

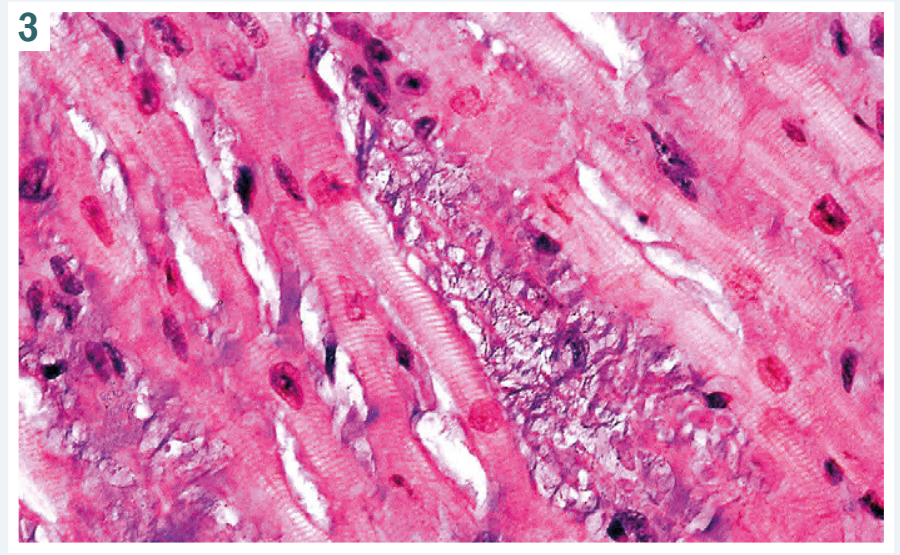

Fig. 3. Loss of transverse striation, blurred borders between myocytes, areas of sclerosis. H-E. Mag. $\times 400$. Polarization microscopy.

the accumulation of cholesterol crystals and large number of foamy macrophages (mainly in the middle membrane of the arteries and to a lesser extent in the intima), there was presence of dystrophic calcinosis, which was not typical for alcoholism group. The most pronounced sclerosis was in arterioles with a diameter of 30-50 microns. Vascular sclerosis of the microvasculature (diameter $7-15$ microns) was also commonly observed. Sclerotic changes in large arterioles were by 1.9 times less pronounced than in patients with IHD. Sclerotic changes in the myocardium were diffuse; uniform perivascular and interstitial components of sclerosis were noted. Sclerotic processes were also expressed in the endocardium, especially in cases of a longer alcohol history. Endocardial thickness was uneven in different divisions (Fig. 4A). In areas of the myocardium that were in contact with the sclerosed sections of the endocardium, pronounced dystrophic changes were observed, since trophic support of these areas occurs from the side of heart cavities. The muscle fibers adjacent to the endocardium were hypertrophied, of different thickness. In hypertrophied myocytes, along with an increase of the cytoplasmic sector and the size of the nucleus, dystrophic changes were also noted, which manifested themselves in limited areas of disappearance of transverse striation along the fiber. Uneven staining of adjacent myocytes was noted due to a change in their physicochemical properties. Areas with severe cardiomyocyte hypertrophy alternated with areas of atrophy, which were located both under the endocardium and intramurally. Between separate bundles of atrophied cardiomyocytes there was a loose connective tissue stroma with alternating areas of more pronounced collagenization.

Accumulations of adipose tissue often found in stroma, which formed small, optically empty cavities with an area of $80-130 \mu \mathrm{m}^{2}$, were located at considerable distance from each other. Patches of adipose tissue were more often located in close proximity to blood vessels. With a long history of alcoholism, adipose tissue formed significant areas or diffusely penetrated myocardium with stratification of cardiomyocytes bundles into individual cells. The total area occupied by adipose tissue in some parts of the heart amounted to $32 \%$ of the field of view of the microscope with magnification of 200 times (Fig. 5A), however, the average values of the fatty degeneration area/field of view did not exceed $6.5 \%$. Cardiomyocytes that were adjacent to adipocytes had a wavy course (Fig. 5A), which is regarded as a possible morphological sign of heart rhythm disturbance. Most of these myocytes were characterized by atrophic changes, some of cells were fragmented. Around the bundles and individual myocytes, a varying severity of the cell-mesenchymal reaction was observed with a predominance of histiocytes, macrophages, and lymphocytes.

The pronounced fatty degeneration was observed in papillary muscle cardiomyocytes. The number of such cardiomyocytes amounted to $60 \%$ of the field of view. Severe fatty degeneration of these myocardium areas, apparently, determined valvular dysfunction in such patients, which was recorded in vivo by instrumental methods. Significant foci of karyocytolysis were noted in subendocardial areas (Fig. 5B).

In $20 \%$ of cases, mosaic necrosis of individual cardiomyocytes and foci of necrosis of small groups of cardiomyocytes, as well as fibrinoid necrosis of small branches of the coronary arteries were found in the myocardium, which was well documented in Masson staining (Fig. 6). In such areas, the presence of stasis in small arterioles and capillaries, stromal edema were detected. 
Morphometric analysis showed that in comparison with the deceased with IHD the number of cardiomyocytes in state of fatty degeneration increased by 1.23 times $(\mathrm{P}<0.05)$ (average area $5.4(4.37 ; 6.27) \%)$ and by 1.38 times $(P<0.05)$ - the number of fuchsinophilic cardiomyocytes (average area $7.04(6.16 ; 8.15) \%)$. The area of sclerotic changes in stroma reached an average of $16.04(14.4 ; 17.15) \%$, which is significantly higher in comparison with IHD and HD group (1.88 and 6.94 times, respectively $(P<0.05))$. In conditions of prolonged alcohol intoxication, sclerotic changes were diffuse in nature and combined with significant atrophic changes in cardiomyocytes.

Based on the obtained data, morphological signs of alcoholic cardiomyopathy (ACMP) can be distinguished, which is characterized by arteriosclerosis and thickening of the walls of the coronary arteries without atherosclerotic changes in these vessels or with minimal signs of atherosclerosis, as well as subendocardial, perivascular and diffuse small focal cardiosclerosis. Uneven hypertrophy and atrophy of muscle fibers, their fragmentation, the presence of adipose tissue accumulations in the stroma and under the endocardium, fatty degeneration of cardiomyocytes and their focal fuchsinophilia are characteristic for ACMP.

\section{Discussion}

The study showed that in IHD, HB and ACMP there are similar morphological changes in heart, and any specific diagnostic criteria associated with the effect of alcohol on the heart are quite difficult to distinguish. Thus, in addition to the direct action of ethanol on cardiomyocytes, chronic micro- and macroangiopathy, as well as increasing perivascular sclerosis, contribute to the development of ACMP. Due to the pathology of the histohematic barriers and the membrane-toxic action of ethanol to the myocardium, heterogeneous changes increase: atrophy, hypertrophy of muscle fibers and replacement sclerosis. In cardiomyocytes, we revealed pronounced fatty degeneration, both parenchymal and stromal, with an increased volume of adipose tissue in the myocardial interstitium (obesity of heart). These processes, as indicated by a number of authors, are progressing due to increasing changes in the metabolic, synthetic and hematopoietic functions of the liver, as well as the result of the neuropathic effect of ethanol on the conduction system of the heart. Our analysis also allows us to say that alcoholism does not exclude the development of atherosclerosis, but atherosclerotic vascular changes are much less pronounced in comparison with IHD and HD. Previous studies confirm that pathomorphological changes in alcoholic cardiomyopathy, IHD, idiopathic dilated cardiomyopathy are not much specific to allow differential diagnosis of these conditions [13]. In relation to hypertension, it should be noted, that HD is a practically obligate component of the alcoholic lesion of the cardiovascular system [14]. In the pathogenesis of alcoholic hypertension, violation of vascular tone regulation plays leading role, which is determined by toxic effect of ethanol on various parts of the nervous system [15].
4A

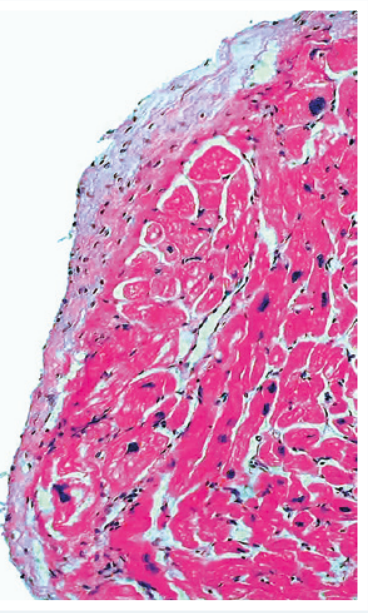

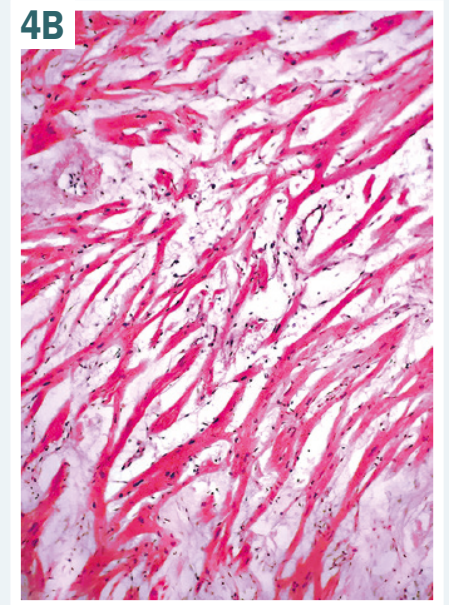

Fig. 4. A: Uneven thickening of the endocardium. H-E. Mag. $\times 400$. B: Severe atrophy of cardiomyocytes. H-E. Mag. $\times 200$.
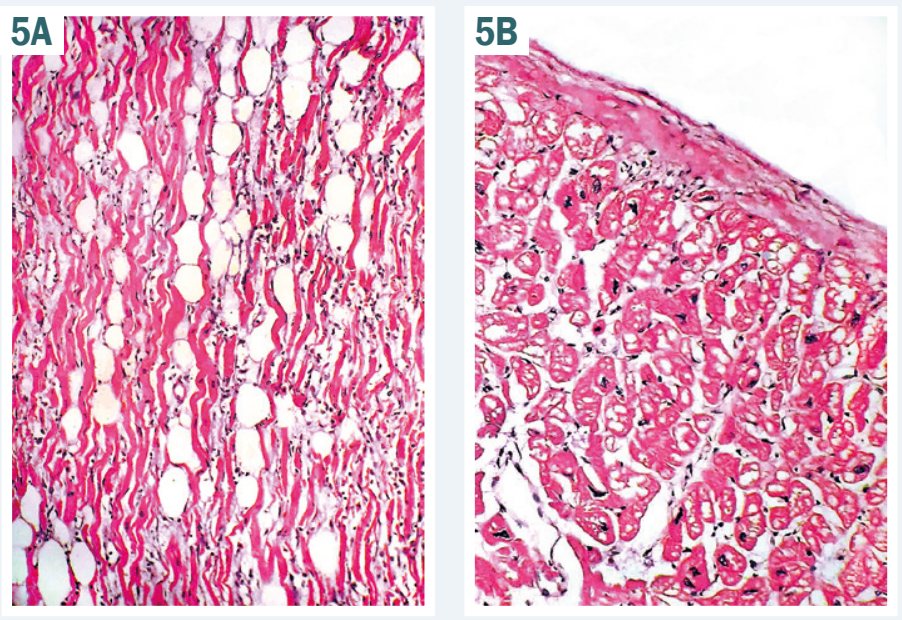

Fig. 5. A: Severe mesenchymal fatty degeneration of the myocardium. Dystrophic and atrophic changes in cardiomyocytes and a diffuse cell-mesenchymal reaction. B: karyocytolysis of cardiomyocytes of the papillary muscles. H-E. Mag. $\times 200$.

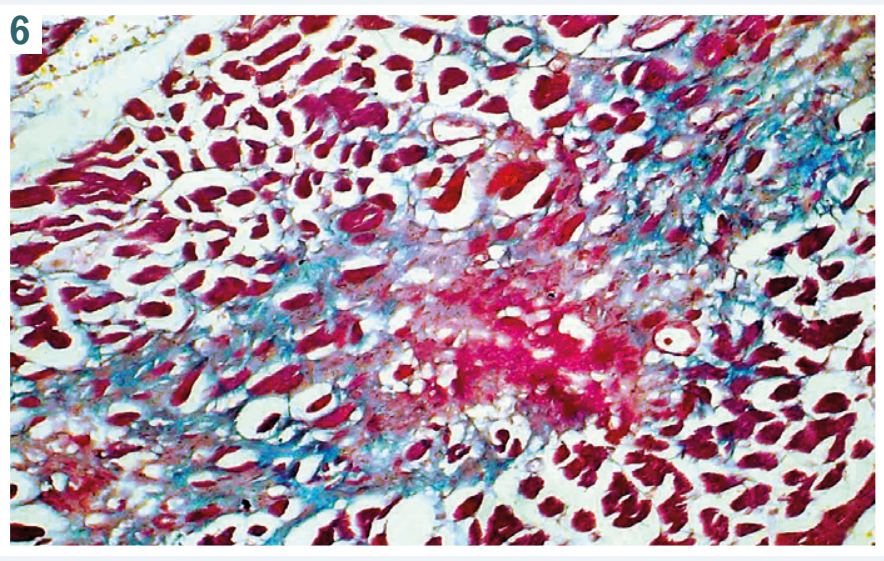

Fig. 6. Fuchsinophilic, homogeneous area of necrosis, surrounded by areas of sclerosis. Interstitial edema. Masson staining. Mag. $\times 200$.

Macroscopic changes in heart of patients with alcoholism are characterized by dilation of heart cavities, excessive accumulation of fatty tissue in the epicardium, while the heart mass was less than in comparison groups. 
The analysis of histological preparations revealed a combination of dystrophic, microcirculatory, sclerotic, atrophic and necrotic changes. Among the most characteristic pathomorphological features of alcoholic cardiomyopathy, microcirculation disorders in the form of aggregation and sludge of erythrocytes in venules, vascular plasmatization, as well as changes in cardiomyocytes such as cardiomyocytolysis and dissociation of cardiomyocytes were noted. Against the background of microcirculatory disorders, stromal edema develops, which is also a characteristic sign of ACMP.

Despite the absence of specific criteria for alcoholic myocardial damage, the most characteristic histological criteria can be distinguished: the alternation of hypertrophic and atrophied cardiomyocytes in a state of severe parenchymal dystrophy; pronounced mesenchymal fatty degeneration; plasmatization of the vascular walls, microcirculatory disorders in the form of erythrocytic stasis, sludge phenomenon and precapillary fibrosis.

Frequently recorded changes in alcoholic damage are sclerotic changes, which in our observations were diffuse, despite the fact that the coronary arteries most often remained intact. Apparently, the pathogenesis of sclerotic changes in alcoholism is not associated with insufficient blood circulation, which was observed in patients with IHD and hypertension, and depends mainly on toxic damage of the vascular wall with the subsequent replacement of irreversibly damaged structures with connective tissue. Most likely sclerosis of arterial network results in decrease of the tone of the intraorganic arteries and, accordingly, the arterial pressure in them also falls, which leads to a decrease in the volume of blood entering the microvasculature. Moreover, it is likely that for a long time the blood supply to organs and tissues is compensated by the formation of new capillaries. However, repeated alcoholic excesses eventually exhaust the compensatory reserves of the body. As a result, the number of capillaries and venules gradually decreases, which leads to progressive metabolic disorders, the progression of chronic hypoxia, followed by increased sclerotic processes in the myocardium. Given the nature of morphological changes in the myocardium, modern therapeutic strategies should be directed on preventing oxidative damage, myocyte hypertrophy, interstitial fibrosis, and cardiomyocyte death [16].

\section{Conclusions}

1. The morphogenesis of heart damage in the conditions of alcoholism consists of a combination of various degrees severity dystrophic, necrotic, atrophic and sclerotic changes, which are the morphological substrate of alcoholic cardiomyopathy.

2. According to morphometric analysis, as compared to the comparison IHD group, myocardium of patients with alcoholism is characterized by increase in number of cardiomyocytes in state of fatty degeneration (by 1.23 times), fuchsinophilic cardiomyocytes (by 1.38 times) and simultaneous reducing of the severity of sclerotic changes in vessels by 1.9 times. Sclerotic changes in stroma are significantly more pronounced in group with alcoholism compared with IHD and HD groups (by 1.88 and 6.94 times, respectively).
3. Pathomorphological changes in the myocardium that occur during alcoholism, based on qualitative and quantitative methods of analysis are important morphological criteria for establishing thanatogenesis and the immediate cause of death.

Conflicts of interest: authors have no conflict of interest to declare. Конфлікт інтересів: віАсутній.

Надійшла Ао редакції / Received: 18.05.2020

Після Аоопрацювання / Revised: 28.05.2020

Прийнято Ао Аруку / Accepted: 02.06.2020

Information about authors:

Tertyshnyi S. I., MD, PhD, DSc, Professor, Head of the Department of Pathological Anatomy and Forensic Medicine, Zaporizhzhia State Medical University, Ukraine.

ORCID ID: 0000-0003-3856-4234

Shuliatnikova T. V., MD, PhD, Associate Professor of

the Department of Pathological Anatomy and Forensic Medicine, Zaporizhzhia State Medical University, Ukraine.

ORCID ID: 0000-0002-0196-9935

Zubko M. D., MD, PhD, Associate Professor of the Department of Pathological Anatomy and Forensic Medicine, Zaporizhzhia

State Medical University, Ukraine.

ORCID ID: $\underline{0000-0002-3683-4010}$

\section{Відомості про авторів:}

Тертишний C. І., А-р меА. наук, професор, зав. каф. патологічної анатомії і судової медицини, Запорізький державний медичний університет, Україна.

Шулятнікова Т. В., канд. меА. наук, Аоцент каф. патологічної анатомії і судової медицини, Запорізький державний медичний університет, Україна.

Зубко М. А., канд. меА. наук, доцент каф. патологічної анатомії і судової меАицини, Запорізький Аержавний медичний університет, Україна.

\section{Сведения об авторах:}

Тертышный С. И., А-р меА. наук, профессор,

зав. каф. патологической анатомии и судебной медицины, Запорожский государственный медицинский университет, Украина.

Шулятникова Т. В., канА. меА. наук, Аоцент каф.

патологической анатомии и судебной медицины,

Запорожский государственный медицинский университет, Украина.

Зубко М. А., канА. меА. наук, Аоцент каф. патологической анатомии и судебной медицины, Запорожский

государственный медицинский университет, Украина.

\section{References}

[1] Witkiewitz, K., Litten, R. Z., \& Leggio, L. (2019). Advances in the science and treatment of alcohol use disorder. Science advances, 5(9), eaax4043. https://doi.org/10.1126/sciadv.aax4043

[2] Pan, X. Q., Zhang, Y. H., Liu, Y. Y., \& Tong, W. J. (2010). Interaction between the C(-344)T polymorphism of CYP11B2 and alcohol consumption on the risk of essential hypertension in a Chinese Mongolian population. European journal of epidemiology, 25(11), 813-821. https:// doi.org/10.1007/s10654-010-9504-y

[3] Piano, M. R. (2017). Alcohol's Effects on the Cardiovascular System. Alcohol Research-Current Reviews, 38(2), 219-242.

[4] Maisch, B. (2016). Alcoholic cardiomyopathy : The result of dosage and individual predisposition. Alkoholische Kardiomyopathie : Eine Folge der Dosis und der individuellen Prädisposition. Herz, 41(6), 484-493. https://doi.org/10.1007/s00059-016-4469-6

[5] Tolstrup, J. S., Wium-Andersen, M. K., Ørsted, D. D., \& Nordestgaard, B. G. (2016). Alcohol consumption and risk of atrial fibrillation: Observational and genetic estimates of association. European journal of preventive cardiology, 23(14), 1514-1523. https://doi. org/10.1177/2047487316641804 
[6] Gillis, A. M. (2020). A Sober Reality? Alcohol, Abstinence, and Atrial Fibrillation. The New England journal of medicine, 382(1), 83-84. https:// doi.org/10.1056/NEJMe1914981

[7] Larsson, S. C., Wallin, A., Wolk, A., \& Markus, H. S. (2016). Differing association of alcohol consumption with different stroke types: a systematic review and meta-analysis. BMC medicine, 14(1), 178. https:// doi.org/10.1186/s12916-016-0721-4

[8] Paloczi, J., Matyas, C., Cinar, R., Varga, Z. V., Hasko, G., Schindler, T. H., Kunos, G., \& Pacher, P. (2019). Alcohol Binge-Induced Cardiovascular Dysfunction Involves Endocannabinoid-CB1-R Signaling. JACC. Basic to translational science, 4(5), 625-637. https:// doi.org/10.1016/i.jacbts.2019.05.007

[9] Rehm, J., \& Roerecke, M. (2017). Cardiovascular effects of alcohol consumption. Trends in cardiovascular medicine, 27(8), 534-538. https://doi.org/10.1016/j.tcm.2017.06.002

[10] Ajani, U. A., Gaziano, J. M., Lotufo, P. A., Liu, S., Hennekens, C. H., Buring, J. E., \& Manson, J. E. (2000). Alcohol consumption and risk of coronary heart disease by diabetes status. Circulation, 102(5), 500-505. https://doi.org/10.1161/01.cir.102.5.500

[11] Steiner, J. L., \& Lang, C. H. (2017). Etiology of alcoholic cardiomyopathy: Mitochondria, oxidative stress and apoptosis. The international journal of biochemistry \& cell biology, 89, 125-135. https://doi. org/10.1016/j.biocel.2017.06.009

[12] Fernández-Solà J. (2020). The Effects of Ethanol on the Heart: Alcoholic Cardiomyopathy. Nutrients, 12(2), 572. https://doi.org/10.3390/ nu12020572

[13] Li, X., Nie, Y., Lian, H., \& Hu, S. (2018). Histopathologic features of alcoholic cardiomyopathy compared with idiopathic dilated cardiomyopathy. Medicine, 97(39), e12259. https://doi.org/10.1097/ MD. 0000000000012259

[14] Husain, K., Ansari, R. A., \& Ferder, L. (2014). Alcohol-induced hypertension: Mechanism and prevention. World journal of cardiology, 6(5), 245-252. https://doi.org/10.4330/wjc.v6.15.245

[15] Matsumoto, C., Miedema, M. D., Ofman, P., Gaziano, J. M., \& Sesso, H. D. (2014). An expanding knowledge of the mechanisms and effects of alcohol consumption on cardiovascular disease. Journal of cardiopulmonary rehabilitation and prevention, 34(3), 159-171. https:/l doi.org/10.1097/HCR.0000000000000042

[16] Fernández-Solà, J., \& Planavila Porta, A. (2016). New Treatment Strategies for Alcohol-Induced Heart Damage. International journal of molecular sciences, 17(10), 1651. https://doi.org/10.3390/ijms17101651 